\title{
Japanese Students' Group Identification, Social Tolerance and Motivation for Intercultural Communication
}

\author{
Shaoyu Ye and Erika Uchida
}

\begin{abstract}
In the last two decades, the number of non-native Japanese residents in Japan has increased dramatically. Accepting more foreigners is part of the globalization at the worldwide level, which requires Japanese natives to be tolerant and understand other cultures in order to become a "multicultural" society. This study aims to investigate the relationship between Japanese students' group identification, social tolerance towards foreigners, and motivation for intercultural communication, considering the effects of social support networks (SSNs) formed through face-to-face (FTF) and instant messaging (IM) interactions. We conducted a self-reported questionnaire, and 200 responses became the analyzed data. The following results were observed. (a) The results of multiple regression analysis showed that respondents' age, English language abilities, experiences in studying abroad, and social tolerance all had significant effects on motivation for intercultural communication. (b) The structural equation modeling (SEM) analysis showed that their group identification had positive effects on their social tolerance, which helped promote motivation for intercultural communication through the mediating effects of their SSNs via IM. The findings support the possibility that improving Japanese students' social tolerance towards foreigners will be helpful in motivating their intercultural communication, and usage of IM is an effective way to achieve that improvement.
\end{abstract}

Key Words-Japanese students, group identification, social tolerance, motivation for intercultural communication.

\section{INTRODUCTION}

In Japan, the number of non-native residents is increasing. According to [1], as of December 2015, the number of foreigners is 2.23 million, which is about $2 \%$ of the entire population. Additionally, the Japanese government has published a policy stating that Japan aims to accept 300,000 international students by 2020 [2]. As of May 2015, the number of international students in Japan is 208,379 (including 56,317 at Japanese Language Institutions) [3]. Reference [4] illustrates these social changes by publishing "Multicultural Symbiotic Societies," which states that people who have different backgrounds, meaning nationalities and ethnicities, should respect cultural differences and try to build an equal relationship in order to live together as community members. In this sense, it can be said that a "multicultural symbiotic" society is indeed becoming a reality in Japan.

However, when we look at the whole society, it is still

Manuscript received December 18, 2016; revised February 23, 2017.

Shaoyu Ye is with the Faculty of Library, Information and Media Science, University of Tsukuba, 3058550 Japan (e-mail: shaoyu@slis.tsukuba.ac.jp).

Erika Uchida is with the University of Tsukuba, 3058550 Japan (e-mail: s1513116@u.tsukuba.ac.jp). difficult to say that the intercultural communication between Japanese people and foreigners goes smoothly. Intercultural communication is a form of communication that aims to share information across different cultures and social groups. This means that it is not one-way action, but mutual interaction. In other words, intercultural communication in Japan not only requires foreigners to understand Japanese culture, learn the Japanese language and acquire Japanese social skills/ behaviors, but also requires Japanese people to be able to understand other cultures and accept the differences to live together.

For most Japanese people, foreigners are out-group members, namely, heterogeneous people. It is suggested that group identification is one of the key factors that influence people's tolerant reaction [5]. People with a higher level of group identification are strongly aware of their identity as a member of the group, and their evaluation of themselves closely correlates with that of their group's. According to the social identity theory [5], [6], the groups to which people belong are an important source of pride and self-esteem. Groups give us a sense of social identity: a sense of belonging to the social world [5], [7]. In order to increase their self-image, people enhance the status of the group to which they belong. Therefore, people divide the world into in-group (us) and out-group (them). Social identity theory states that the in-group will discriminate against the out-group to enhance the in-group members' self-image, and this was supported by plenty of studies. However, [8] suggested that people with a higher level of group identification are more socially tolerant towards newcomers because they share the same interest in the same group. In fact, the similar implications were reported in other countries through intercultural communication online (e.g., [9], [10]). On this basis, it is possible that Japanese people would be more socially tolerant towards foreigners who are interested in Japanese culture, Japanese language and the society. Therefore, we believe that the following hypothesis will be true:

H1: Japanese students with a higher level of group identification and social tolerance will be more motivated to communicate with foreigners (path $a$ and path $b$ in Fig. 1).

Two decades ago, [11] investigated Japanese students' social support networks (SSNs) to clarify their functions in adaptation and compared the SSNs with those of international students who studied in Japan. The term "social support network" for international students is a general psychological term indicating personal relationships that can be expected to provide both tangible and intangible support and to promote their intercultural communication and thereby adaptation. In order to clarify the relationship between SSNs 
and adaptation, [11] conducted a self-reported questionnaire survey targeting 133 Japanese students (average age: 19.6 years) in 1996. As a result, they found that the average number of their SSNs through face-to-face (FTF) interactions was 6.52, which was slightly larger than international students'. Among their SSNs, 99.6\% were Japanese and only $0.4 \%$ were foreigners. Additionally, $44.8 \%$ were students at the same university, $17.5 \%$ were other friends/acquaintances, $17.3 \%$ were families/relatives, and so on. Another survey on international students' SSNs, conducted in the same period, included 56\% Japanese people [12]. Therefore, [11] suggested that there is high homogeneity among Japanese students' SSNs. However, the above findings were based on FTF because people did not use computers or mobile phones, smartphones, etc., to communicate at that time. Considering the social changes in Japanese society mentioned earlier and that currently people use various media to communicate with each other, it is necessary to investigate Japanese students' SSNs including these factors' influences.

In Japan, before smartphones became popular and nearly ubiquitous, cell phones had been used since 1999 not only as traditional telephones but also to access the Internet and to send and receive text messages, including short message service (SMS). Since 2008, when the iPhone 3G was first launched, smartphones have become the most popular mobile devices used in Japan. This usage has largely changed people's communication styles. For instance, it is found that high school students in Belgium and adults in South Korea form more intimate relationships by sending text messages and making phone calls via various instant messaging (IM) applications, or by sending emails and other messages based on FTF interactions, than by relying only on FTF interactions [13] [14], and similar results were also reported in the case of Japanese university students [15]. Currently, people can transmit information simultaneously to a larger number of people via social media such as Facebook and Twitter, while also sending text messages and/or making voice/video calls to a specific person using "messengers." As Japanese students seldom make voice calls and send fewer emails compared to IM [15], this study focuses on Japanese students' IM usage and their SSNs formed through it, and compares them to those through FTFs, including the relationship between FTF interactions and online interactions. From the viewpoint of synchronicity and asynchoronicity, compared to FTF interactions, IM allows people to think, edit, and even find tools to translate when communicating in foreign languages since they do not need to respond immediately as FTF requires. As [16] indicated, having more friends who are Chinese international students will be helpful in raising Japanese students' liking of them. Based on this, we believe that if Japanese students are able to form stable relationships with foreign people, it will be helpful in raising their liking of them, and therefore, help the two groups to understand each other and communicate more. Thus, we propose the following hypothesis:

H2: Japanese students' SSNs including more foreigners will have a positive effect on their motivation for intercultural communication (path $d$ in Fig. 1).

Finally, [17] found that high school students' use of cell phone text messages encourages them to select homogeneous others as companions of communication and, therefore, brings a bias of homogeneity into their personal networks. This homogeneity bias, in turn, will have a negative effect on the development of social tolerance in the socialization process by reducing the chance of interaction with heterogeneous people. In contrast, they found that compared to cell phone text messages, emails via computer have a positive effect on social tolerance because they allow for mediating communications with heterogeneous people [18]. In Japan, people use cell phone text messages to form "strong ties" with those they often meet, such as family, lovers, friends, and so on, whereas emails via computer are used to form "weak ties" with those they do not contact frequently [19]. Therefore, they suggested promoting people accessing the Internet more through computers in order to enlarge their personal networks with heterogeneous people [18]. However, there is the possibility that the opposite direction may also exist. That is, not only does media usage influence users' social tolerance, but their social tolerance influences their media usage. As mentioned earlier, socially tolerant people will be able to communicate with heterogeneous people more, and this will be the same when using communication media.

Currently, only a few people use regular cell phones to send the so-called cell phone text messages, while $96.3 \%$ of the university students use LINE to communicate with others [15]. From the viewpoint of immediacy and strengthening their "selective" relationships, IM can be considered the same as traditional cell phone text messages since users can choose whom they should/should not contact or even ignore the messages that are shown as "Kidoku" (meaning "already read"), while FTF interactions seem to be more unavoidable. As mentioned earlier, if Japanese students consider those foreigners who are interested in the Japanese culture and the Japanese society, and share more in common with each other, they might be more tolerant towards foreigners and, therefore, will use IM to communicate with foreigners. Thus, we propose the following hypothesis:

H3: Japanese students with higher levels of social tolerance will be able to form SSNs with foreigners, which will be more obvious when communicating through IM than FTF (path $c$ in Fig. 1).

\section{METHOD}

To examine the above three hypotheses, we conducted a self-reported questionnaire. The participants were Japanese native students enrolled at the University of Tsukuba, a national university in Ibaraki Prefecture near Tokyo. The survey was conducted from mid-July to mid-August in 2016. We distributed the questionnaire to 377 students, 212 of whom submitted responses (recovery percentage: $56.2 \%$ ). Of these, 200 were analyzed in this study. The remaining responses were unusable due to incompleteness.

The survey included four parts - Part A, Part B, Part C, and Part D-with the content in each part as follows.

Part A gathered their personal information including demographic data (e.g., gender, age and academic standing), their experience in studying abroad, English language 
abilities (e.g., score of TOEIC, TOEFL, Eiken) and other language abilities (see Table I).

Part B measured the students' use of media, including regular cell phones/smartphones, computers, and their daily accessing time of the Internet via these devices measured by a 7-point scale ("7. Over 6 hours"; "4. 3-4 hours"; "1. Less than 1 hour"), which is also reported in Table I.

Part C gathered information about students' SSNs through FTF and IM communications. Following the definition of [11][12], we defined the "SSNs" as "important relationships in their daily lives" and asked the students to list UP TO 10 people they had met in person or sent instant messages to in the previous three months for important conversations. For each SSN, students were asked to provide their contact person's gender, age, nationality, language used when communicating, relationship, and frequency of contact (from "4. Almost every day" to "1. Less than once per month"), as well as the main content of the communication and importance of the person in their lives ("5. Very important"; "3. Moderately important"; "1. Not important at all"). Additionally, the students were asked to answer whether the person(s) listed in the SSNs via IM was/were also listed in those via FTF, and so on (Tables II and III).

Part D measured students' group identification (7 items, see Table IV) and social tolerance (11 items, see Table V) ${ }^{1}$, which were chosen from [8]. We used a 6-item scale to measure their motivation for intercultural communication [20]. Originally, this scale was developed for international students' motivation to communicate with Japanese people, so we revised some expressions so that they could be used to measure Japanese students (see Table VI). The respondents were asked to rate all these scales using a 5-point scale ("5. Strongly agree"; "3. Neither"; "1. Strongly disagree").

\section{- Analysis of the Causal Relationships}

This study sought to examine the relationships between group identification, social tolerance, and motivation for intercultural communication (Fig. 1). As mentioned in the previous part, Hypothesis 1 examined path $a$ and path $b$, Hypothesis 2 examined path $d$, and Hypothesis 3 examined path $c$. We compared the results between the SSNs formed via FTF and those via IM.

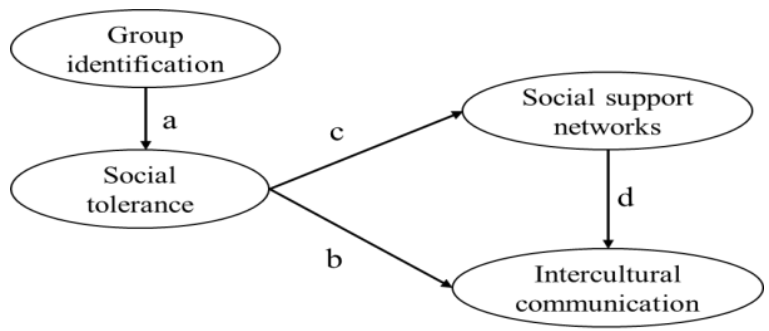

Fig. 1. The analyzed model in this study.

\section{RESULTS}

\section{A. Descriptive Results}

For details regarding demographics of the 200 students (e.g., gender ratio, average age, device ownership rates, etc.),

\footnotetext{
${ }^{1}$ We did not use the item of "I am concerned whether the interpersonal relationship in the present group will be broken or not."
}

see Table I. Out of all 200 total responses, 83.5\% were undergraduates and nearly $10 \%$ had experience in studying abroad. Regarding their English abilities, 30.5\% had taken TOEIC and $53.0 \%$ had taken Eiken $(10.5 \%$ had taken both TOEIC and Eiken); only $26.5 \%$ of respondents had not taken any foreign language exams. Additionally, we found that 95.5\% of them used either an iPhone or Android, and 95\% of them had their own personal computers. Regarding their accessing time of the Internet, we found that male students used mobile devices more than computers to access the Internet for periods of 1-3 hours, while in other cases they used computers more. In contrast, females used mobile devices more than computers to access the Internet (1-6 hours). These differences were significant. For mobile devices, males vs. females: 2.90 vs. $3.28, t(198)=1.99, p<.05$; for computers, males vs. females: 3.49 vs. $2.59, t(149)=3.51$, $p<.01$.

TABLE I: INFORMATION FOR ANALYZED STUDENTS

\begin{tabular}{|c|c|c|c|}
\hline & Male (84) & Female (116) & Overall (200) \\
\hline Age (in years) & 20.7 & 19.4 & 19.9 \\
\hline \multicolumn{4}{|l|}{ Academic standing: } \\
\hline Undergraduate & 61 & 106 & $167(83.5 \%)$ \\
\hline Graduate (Master) & 23 & 10 & $33(16.5 \%)$ \\
\hline Experience abroad & 3 & 14 & $17(8.5 \%)$ \\
\hline \multicolumn{4}{|l|}{ Foreign languages } \\
\hline TOEIC & 31 & 30 & $61(30.5 \%)$ \\
\hline Eiken & 42 & 64 & $106(53.0 \%)$ \\
\hline TOEFL-ITP & 1 & 2 & $3(1.5 \%)$ \\
\hline Other languages & 2 & 2 & $4(2.0 \%)$ \\
\hline Not taken any & 19 & 34 & $53(26.5 \%)$ \\
\hline \multicolumn{4}{|l|}{ Possession of devices } \\
\hline Cell phones & 4 & 4 & $8(4.0 \%)$ \\
\hline iPhones & 48 & 63 & $111(55.5 \%)$ \\
\hline Androids & 31 & 49 & $80(40.0 \%)$ \\
\hline Computers & 82 & 108 & $190(95.0 \%)$ \\
\hline Internet accessing time & \multicolumn{3}{|c|}{ Mobile devices vs. computers } \\
\hline$<1$ hour & 6 vs. 16 & 9 vs. 31 & 15 vs. 47 \\
\hline $1-2$ hours & 27 vs. 14 & 24 vs. 33 & 51 vs. 47 \\
\hline $2-3$ hours & 35 vs. 20 & 40 vs. 28 & 75 vs. 48 \\
\hline 3-4 hours & 8 vs. 8 & 24 vs. 13 & 32 vs. 21 \\
\hline $4-5$ hours & 3 vs. 8 & 10 vs. 3 & 13 vs. 11 \\
\hline $5-6$ hours & 3 vs. 9 & 5 vs. 4 & 8 vs. 12 \\
\hline$>6$ hours & 2 vs. 9 & 4 vs. 4 & 6 vs. 13 \\
\hline
\end{tabular}

\section{B. Configurations of Their SSNs}

Prior to examining the relationship between the students' group identification, social tolerance and motivation for intercultural communication, we needed to investigate the configurations of each SSN. It is necessary to note that not every student used IM to communicate with others. In fact, only $92 \%$ of the respondents used IM. Table II shows the average number of people in each SSN and their relationships. As mentioned earlier, we asked the respondents to list up to 10 persons for important conversations in the last three months, so the maximum number for each SSN is 10 . The contact frequency ranges from " 4 . Almost every day" to "1. Less than once per month," so the maximum for their contact frequency of the entire SSN is 40. Similarly, the maximum of 
contact persons' importance is calculated as $5 \times 10=50$ (the 5 -point scale is from " 5 . Very important" to " 1 . Not important at all"). As a result, we found that those SSNs via FTF were larger than those via IM, and the configuration of foreigners in IM was almost the same as that via FTF, and most contacts through IM were also those they met in person frequently.

\section{TABLE II: STUDENTS' SSNS FORMED THROUGH FTF AND IM}

\begin{tabular}{lcc}
\hline \hline & Japanese (M) & Foreigners(M) \\
\hline FTF & $5.06(96.8 \%)$ & $.17(3.2 \%)$ \\
$\quad$ Number of contacts & $12.35(96.7 \%)$ & $.43(3.3 \%)$ \\
$\quad$ Contact frequency & $17.28(96.7 \%)$ & $.59(3.3 \%)$ \\
$\quad$ & & \\
$\quad$ Importance of contacts & $3.83(96.2 \%)$ & $.15(3.8 \%)$ \\
$\quad$ Number of contacts & $9.28(97.4 \%)$ & $.25(2.6 \%)$ \\
$\quad$ Contact frequency & $13.27(97.1 \%)$ & $.40(2.9 \%)$ \\
$\quad$ Importance of contacts & $2.05(80.4 \%)$ & $.50(19.6 \%)$ \\
\hline Relation between FTF \& IM & &
\end{tabular}

TABLE III: STUDENTS' SSNS WITH FOREIGNERS VIA FTF AND IM

\begin{tabular}{|c|c|c|}
\hline Foreigners & FTF (29 persons) & IM ( 28 persons) \\
\hline \multirow{5}{*}{ Age: } & Under 20 years: 4 & Under 20 years: 5 \\
\hline & 20-29 years: 15 & 20-29 years: 17 \\
\hline & 30-39 years: & $30-39$ years 3 \\
\hline & Over 40 years: & Over 40 years: 2 \\
\hline & Unknown: 1 & Unknown: 1 \\
\hline \multirow{2}{*}{$\begin{array}{l}\text { Language } \\
\text { used }\end{array}$} & Japanese: 20 & Japanese: 10 \\
\hline & Foreign languages: 9 & Foreign languages: 18 \\
\hline \multirow{9}{*}{$\begin{array}{l}\text { Relationships } \\
\text { (multiple) }\end{array}$} & Friends: 4 & Friends: 13 \\
\hline & Acquaintances:3 & Acquaintances : 11 \\
\hline & Family/relatives: 3 & Family/relatives: 2 \\
\hline & Academic advisor: 1 & Academic advisor: 2 \\
\hline & Students at the same & Students at the same \\
\hline & Univ.: 15 & Univ.: 6 \\
\hline & Other faculty: 1 & Other faculty: 0 \\
\hline & Part-time job: 1 & Part-time job: 2 \\
\hline & Others: 1 & Others: 0 \\
\hline \multirow{3}{*}{$\begin{array}{l}\text { Contact } \\
\text { frequency } \\
\text { (multiple) }\end{array}$} & At least once/week: 9 & At least once/week: 4 \\
\hline & At least once/month: 14 & At least once/month: 11 \\
\hline & Less than once/month: 6 & Less than once/month: 13 \\
\hline \multirow{6}{*}{$\begin{array}{l}\text { Main content } \\
\text { (multiple) }\end{array}$} & Study/research:14 & Study/research:7 \\
\hline & $\begin{array}{l}\text { Consultation/encourage } \\
\text { ment: } 9\end{array}$ & $\begin{array}{l}\text { Consultation/encourage } \\
\text { ment: } 5\end{array}$ \\
\hline & $\begin{array}{l}\text { Going out together/ } \\
\text { entertainment }: 7\end{array}$ & $\begin{array}{l}\text { Going out together/ } \\
\text { entertainment : } 7\end{array}$ \\
\hline & $\begin{array}{l}\text { Getting information for } \\
\text { daily living: } 10\end{array}$ & $\begin{array}{l}\text { Getting information for } \\
\text { daily living: } 7\end{array}$ \\
\hline & Chatting: 14 & Chatting: 15 \\
\hline & Other: 1 & Other: 1 \\
\hline \multirow{3}{*}{ Importance } & & Very important: 9 \\
\hline & Somewhat important: 7 & Somewhat important: 11 \\
\hline & Not so important: 4 & $\begin{array}{l}\text { Not so important: } 7 \\
\text { Not important at all:1 }\end{array}$ \\
\hline Listed in FTF & -- & Yes: $10 ; \quad$ No: 18 \\
\hline
\end{tabular}

The configurations of foreigners formed through FTF and IM are shown in Table III. From the results, we found that the number of foreigners through two SSNs was almost the same. In addition, there were also differences between the two SSNs. First, when communicating in person, over $2 / 3$ spoke in Japanese; however, when communicating through IM, nearly $2 / 3$ used foreign language. Second, most of the partners they met in person were students at the same university, while most of the partners were friends and acquaintances when interacting through IM. Third, although the importance of the foreigners whom they met in person was larger than the importance of those through IM, Japanese students did use IM to communicate with those whom they did not meet in person frequently since nearly $2 / 3$ were not listed in the FTF SSNs. But no gender differences were detected among their SSNs formed either via FTF or IM.

\section{Internal Reliability for Each Scale}

Tables IV through VI show the items and average score for group identification, social tolerance and motivation for intercultural communication. We confirmed the scale's internal reliability by calculating its Cronbach's $\alpha$ coefficients. As a result, coefficients for the three scales were $.89, .80$, and .92 , respectively. These all showed high internal reliability. We also conducted a $t$-test (independent sample) to confirm whether there was any difference due to gender. As a result, females' scores for social tolerance were significantly higher than males $(t(198)=2.69, p<.01$; male vs. female: 37.74 vs. 40.09), and females' scores for group identification were slightly higher than males $(t(149)=1.94$, $p<.10)$. However, no gender differences were detected in their motivation for intercultural communication.

\section{TABLE IV: ITEMS OF GROUP IDENTIFICATION AND MEAN SCORE}

\begin{tabular}{lc} 
Items & Mean \\
\hline $\begin{array}{l}\text { 1. It is accurate to say that I am a typical member of } \\
\text { the group I belong to. }\end{array}$ & 3.22 \\
$\begin{array}{l}\text { 2. It makes me feel good that I am one of the members } \\
\quad \text { of the group I belong to. }\end{array}$ & 3.47 \\
3. There are many people important to my life in the & 3.78 \\
$\quad \begin{array}{l}\text { same group. } \\
\text { 4. I am aware that I am a member of that group. }\end{array}$ & 3.68 \\
5. I have attachment to that group. & 3.84 \\
6. There are many people who influence my opinions & 3.70 \\
$\quad$ and behaviors in the same group. & 3.84 \\
7. Many of my close friends are in the same group. & \\
\hline \multicolumn{2}{l}{$\alpha=.89$}
\end{tabular}

TABLE V: ITEMS OF SOCIAL TOLERANCE AND MEAN SCORE

\begin{tabular}{lc} 
Items & Mean \\
\hline $\begin{array}{l}\text { 1. I will talk to the new members while considering } \\
\text { their feelings. }\end{array}$ & 3.66 \\
$\begin{array}{l}\text { 2. I will try to know the new members actively. } \\
\text { 3. I would like to know all the aspects of the new }\end{array}$ & 3.50 \\
members. & 3.49 \\
$\begin{array}{l}\text { 4. I will tell the new members about the group } \\
\text { actively. }\end{array}$ & 3.28 \\
$\begin{array}{l}\text { 5. I try to make others familiar with new members. } \\
\text { 6. I try to keep in touch with others. }\end{array}$ & 3.12 \\
$\begin{array}{l}\text { 7. I try to take care to others eligibly. } \\
\text { 8. I always judge others immediately*. } \\
\text { 9. It is pleasurable that people become new members }\end{array}$ & 3.47 \\
$\quad \begin{array}{l}\text { of the group and I will actively accept them. } \\
\text { 10. Even if the person is heterogeneous with others in } \\
\quad \text { the group, I will definitely accept them. }\end{array}$ & 3.34 \\
$\begin{array}{l}\text { 11. I would like to avoid talking with people whose } \\
\quad \text { opinions are different from mine*. }\end{array}$ & 2.92 \\
\hline \begin{tabular}{l}
$\alpha=80$ (Note: * refers to reversal items ) \\
\hline
\end{tabular} & 2.46 \\
\hline
\end{tabular}


TABLE VI: ITEMS OF MOTIVATION FOR INTERCULTURAL COMMUNICATION AND MEAN SCORE

\begin{tabular}{lc}
\hline \hline Items & Mean \\
\hline $\begin{array}{l}\text { 1. I would like to talk to foreigners. } \\
\text { 2. I would like to become friends with foreigners. }\end{array}$ & 3.52 \\
$\begin{array}{l}\text { 3. I would like to express my thoughts to foreigners by } \\
\quad \text { using foreign language. }\end{array}$ & 3.47 \\
$\begin{array}{l}\text { 4. I am interested in foreign languages and } \\
\quad \text { intercultural communication. }\end{array}$ \\
$\begin{array}{l}\text { 5. I would like to master the pronunciation when } \\
\quad \text { talking with foreigners using a foreign language. }\end{array}$ \\
$\begin{array}{l}\text { 6. I would like to pronounce like normal Japanese } \\
\quad \text { people when speaking in a foreign language. }\end{array}$ \\
\hline $\begin{array}{l}\alpha=.92 \\
\end{array}$
\end{tabular}

\section{A. Analysis of Causal Relationship}

Before conducting the structural equation modeling (SEM) analysis, it is necessary to detect which factor(s) influenced the students' motivation for intercultural communication.

Previous studies have indicated that factors such as age, gender and language abilities, experience in studying abroad influence people's intercultural communication [e.g., 21]. Therefore, in order to confirm these factors' effects, along with group identification and social tolerance's, we conducted multiple regression analysis, adding age, gender, experiences in studying abroad, English language abilities, group identification and social tolerance as independent variables $^{2}$. The results showed that age $(\beta=-.20, p<.01)$, experiences in studying abroad $(\beta=.16, p<.05)$, English language abilities $(\beta=.26, p<.001)$ and social tolerance $(\beta=.28$, $p<.001)$ had significant effects on their motivation for intercultural communication. The adjusted $\mathrm{R}$ square for this model was .20, $p<.001$. Fig. 2 shows the results. From it, we found that the younger students with higher levels of English language ability and experience in studying abroad, as well as higher levels of social tolerance, would like to communicate with foreigners more.

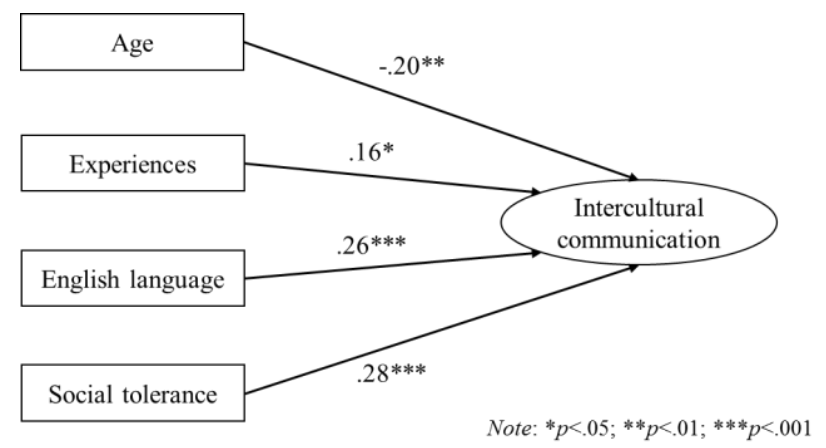

Fig. 2. Results of multiple regression analysis.

${ }^{2}$ As TOEIC and Eiken have different standards and evaluations, we calculated their English language ability based on their TOEIC scores: (1) for those with TOEIC scores: their score/990; (2) for those with Eiken scores: Grade 1=TOEIC 955/990; Grade Pre-1=TOEIC 713/990; Grade 2=TOEIC 527/990, Grade Pre-2=TOEIC 402/990, and so on. For those who did not take any exam, their score was calculated as 0 ; (3) for those who took both TOEIC and Eiken or TOEIC and TOEFL, we calculated their TOEIC scores.
Next, we conducted the SEM analysis, as Fig. 1 shows. Here, SSNs refers to the number of foreigners with whom they communicate, the contact frequency with them and their importance to the respondents in both FTF and IM. Group identification included the 7 items shown in Table IV, social tolerance included the 11 items shown in Table $\mathrm{V}$, and motivation for intercultural communication included the 6 items shown in Table VI. Fig. 3 and Fig. 4 show the SEM results for FTF and IM, respectively. The model fits of these two figures were: $\chi^{2}(d f=320)=672.85, p<.001, \mathrm{GFI}=.805$, $\mathrm{CFI}=894, \mathrm{RMSEA}=.074 ; \chi^{2}(d f=320)=714.70, p<.001, \mathrm{GFI}$ $=.804, \mathrm{CFI}=874$, RMSEA $=.079$, which were acceptable. From the figures, we found that group identification had positive effects on social tolerance, which led to higher level of motivation for intercultural communication. Additionally, socially tolerant students tended to form larger SSNs with foreigners using IM $(p=.58)$, which had slightly positive mediating effects on their motivation for intercultural communication $(p=.83)$, but no similar mediating effects could be detected in the case of FTF.

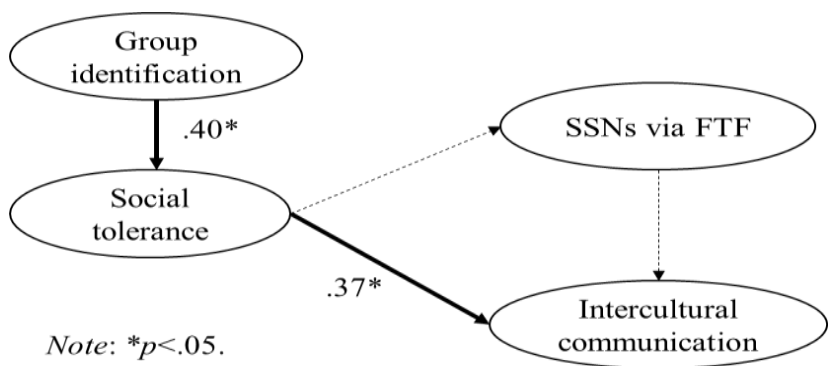

Fig. 3. The SEM results for FTF.

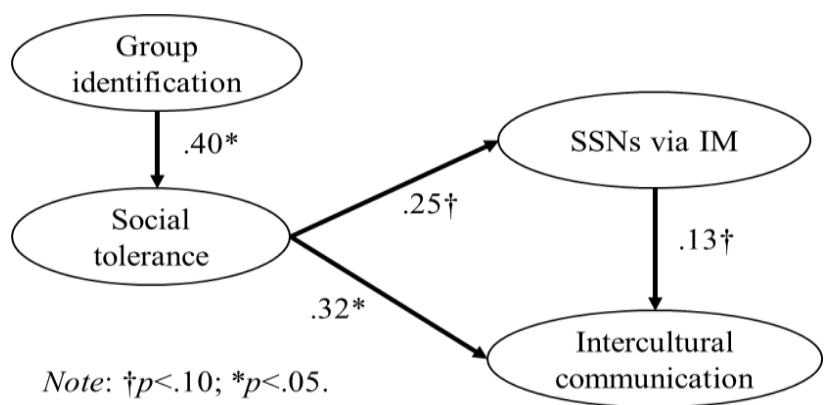

Fig. 4. The SEM results for IM.

In sum, (a) for FTF interaction, only direct effects of social tolerance on motivation for intercultural communication were detected; (b) for IM usage, not only direct effects of social tolerance, but also the indirect effects through SSNs on motivation for intercultural communication, were found.

\section{DISCUSSION}

\section{A. Main Findings}

The present study investigated the relationship between Japanese students' group identification, social tolerance and motivation for intercultural communication, including social tolerance's effects on communication with foreigners that might indirectly improve their motivation for intercultural communication. The results indicate that group identification had positive effects on social tolerance, which helped raise their motivation for intercultural communication (H1). In 
addition, Japanese students with higher levels of social tolerance tended to communicate with more foreigners, which had slightly positive mediating effects on their motivation for intercultural communication $(\mathrm{H} 2$ and $\mathrm{H} 3)$. Therefore, H1 was fully supported, and $\mathrm{H} 2$ and $\mathrm{H} 3$ were marginally supported. These findings supported the implication that once Japanese students consider their contact foreigners as in-group members, namely, homogenous partners, they are more tolerant towards them and, therefore, are motivated for intercultural communication. However, if Japanese students consider foreigners as out-group members, namely, heterogeneous people, there are no effects on intercultural communication. This would be the main reason why group identification had no direct effects on their motivation for intercultural communication, as the multiple regression results showed.

TABLE VII: THE NUMBER OF JAPANESE STUDENTS AND INTERNATIONAL STUDENTS' SSNS IN DIFFERENT PERIOD

\begin{tabular}{|c|c|c|}
\hline Forms of SSNs & $\begin{array}{l}\text { Japanese } \\
\text { (M) }\end{array}$ & $\begin{array}{c}\text { International(M } \\
)\end{array}$ \\
\hline \multicolumn{3}{|l|}{ FTF } \\
\hline $\begin{array}{l}\text { Tanaka et al. (1997) } \\
\text { [11] }\end{array}$ & 6.58 & 6.28 \\
\hline Tanaka (2000) [12] & -- & 7.76 \\
\hline Ye et al. (2016) [15] & 6.57 & -- \\
\hline The present study & 5.23 & -- \\
\hline \multicolumn{3}{|l|}{ Voice calls } \\
\hline $\operatorname{Kim}(2003)$ [23] & -- & 6.80 \\
\hline $\begin{array}{l}\text { Ye \& Murota (2015) } \\
\text { [24] }\end{array}$ & -- & $6.96 \& 7.56$ \\
\hline \multicolumn{3}{|l|}{ IM } \\
\hline $\begin{array}{l}\text { Ye \& Murota (2015) } \\
{[24]}\end{array}$ & -- & $7.74 \& 7.99$ \\
\hline Ye et al. (2016) [15] & 4.94 & -- \\
\hline The present study & 3.98 & -- \\
\hline \multicolumn{3}{|l|}{ Email } \\
\hline $\begin{array}{l}\text { Ye \& Murota (2015) } \\
{[24]}\end{array}$ & -- & $6.31 \& 7.06$ \\
\hline Ye et al. (2016) [15] & 2.57 & -- \\
\hline
\end{tabular}

Additionally, improving the Japanese students' social tolerance towards foreigners will not only be helpful in motivating their communication with foreigners directly, but also in forming and maintaining their SSNs through IM communication. This is the positive way for technology that our study suggests. Prior studies have suggested that users' personal networks through cell phone text messages almost always include homogeneous people [17], and users are less tolerant compared to email users through computers [18]. However, our results showed that in the case of intercultural communication, there is another possibility. In fact, the number of Japanese students' SSNs is becoming smaller overall. Table VII shows the number of Japanese students' and international students' SSNs in different periods formed through different communication media. From these results, we found that international students' number of SSNs seems more stable regardless of the communication media in different periods, while the number of Japanese students' SSNs through FTF was almost the same in the surveys of [11] and [15], which were conducted about 20 years apart. These results support the claim that cell phone and smartphone usage may not be able to enlarge users' social networks, but may strengthen their relationships with those who are physically nearby [22]. The main reason that, compared to [11] and [15], the number of Japanese students' SSNs was the smallest in this study might be that we focused on measuring their intercultural communications more than the other two studies. As Table III shows, although the overall number of SSNs via FTF is larger than that of IM, the number of contact foreigners is almost the same. This allows us to assume that it might be difficult for the Japanese students to control or decide whom they should/should not meet since they might meet with each other in the laboratories, during classes, and so on. However, there is a much larger space for them to choose whom they should contact through IM since it is "selective" as cell phone text messages.

Furthermore, we also found that the contact persons through FTF interaction were more "formal" since half of them were "students at the same university" (see Table III), while most of the contact persons through IM interactions were "friends/acquaintances," which seems to be more casual and intimate and support previous studies [17], [19]. In this sense, it is difficult to say that IM usage inhibits Japanese students' intercultural communication. However, it is necessary to note that different people with cultural differences have different preference of media usage (e.g., [7], [16], [25]). In particular, people with high-context cultures such as Japanese, and people with low-context cultures such as Americans, have different choices of media even communicating to the same targets ([26], [27]). For instance, when communicating with professors at universities, American students prefer to send emails while Japanese students prefer to talk through FTF [26]. However, when communicating with intimate friends and acquaintances, Japanese students prefer to send text messages through IM [15] while Chinese students prefer to make phone calls [16]. Considering that different media (especially social media) usage may have different impacts on different aspects of intercultural communication [25], [28], and the fact that Japanese young generation prefer to text messages than other communication media [22], it is necessary to examine whether IM usage will be helpful in promoting intercultural communication in other cultures or not in the future.

Finally, considering the positive effects of social tolerance on their SSNs (Fig. 3) allows us to believe that Japanese students with higher levels of social tolerance will be more tolerant when responding to their contact partners' grammar errors or unsuitable Japanese expressions, and will also be willing to spend time sending text messages in foreign languages. In this study, foreigners not only referred to international students, but also included faculty members such as academic advisors and co-workers in the workplace for part-time jobs. Therefore, our findings may not be the same as those with international students only. However, considering that meeting and/or communicating with foreign faculty members on-campus, and meeting other foreigners (such as part-time workers) off-campus have become more and more common in Japanese society, we believe that our findings will be able to provide some insights into the fields of intercultural communication and media usage in the future. 


\section{B. Limitations and Future Research}

In this study, we examined Japanese students' SSNs formed through IM, which mainly referred to their "personal" usage. Currently, it is common for people to use various social media such as Twitter, Facebook, LINE, and Instagram to maintain their relationships with different people, saying "Good" or commenting on other people's posts, twitting or re-twitting on Twitter, and making self-disclosure on their own pages, while also use the messaging functions to make calls or send messages to a specific person. In other words, these media usages are "social" and "personal." Up until now, social support mainly has referred to "strong ties" that are formed through intimate personal communication. However, it is suggested that "weak ties" may also offer other support [29]. In this sense, it would be desirable for future research to include these points.

\section{CONCLUSION}

In conclusion, we would like to propose that it is necessary to consider ways of education that increase and encourage international contact which are helpful in improving their foreign language abilities and experience in communicating with out-group members. These ways, therefore, will help raise people's social tolerance towards out-group members in the future. Additionally, considering that the size of Japanese students' SSNs through FTF has become smaller and since socially tolerant students tend to form SSNs with foreigners through IM, it is possible for the Japanese students to take advantage of this technology to improve their motivation for intercultural communication in the future.

\section{ACKNOWLEDGMENT}

The authors would like to thank all the students who helped answer this questionnaire survey.

\section{REFERENCES}

[1] Ministry of Justice. (2016). Trends in the number of foreigners' nationality. [Online]. Available: http://www.moj.go.jp/content/001178165.pdf

[2] Ministry of Education, Culture, Sports, Science and Technology (MEXT). (2008). The outline of Japan's system for international students (Wagakuni no ryugakuseiseido no gaiyo). [Online]. Available: http://www.mext.go.jp/a_menu/koutou/ryugaku/081210.pdf

[3] Japan Student Services Organization (JASSO). (2016). Result of an annual survey of international students in Japan 2015. [Online]. Available:

http://www.jasso.go.jp/about/statistics/intl_student_e/2015/_icsFiles/ afieldfile/2016/03/14/data15.pdf

[4] Ministry of Land, Infrastructure, Transport and Tourism (MLIT). (2007). How to create a multicultural coexistence in North Kanto Region (Kitakantoken niokeru tabunkakyosei no chiikizukuri nimukete). [Online]. Available:

http://www.mlit.go.jp/kokudokeikaku/souhatu/h18seika/04kitakantou/ 04_02honpen1.pdf

[5] H. Tajfel and J. C. Turner, "The social identity theory of intergroup behavior," in Psychology of Intergroup Relations, S. Worchel \& W.G. Austin, Eds. Chicago: Nelson-Hall, 1986, pp. 7-24.

[6] A. W. Kruglanski and D. M. Webster, "Motivated closing of the mind: 'Seizing' and 'freezing'," Psychological Review, vol. 103, no. 2, pp. 263-283, April 1996.

[7] R. Shuter, "When Indian women text message: Culture, identity, and emerging interpersonal norms of new media," in New Media and Intercultural Communication: Identity, Community and Politics, P. H. Cheong, J. N. Martin \& L. Macfadyen, Eds. New Yourk, NY: Peter Lang. pp. 209-222.
[8] Z. Uemura, "Ambiguity tolerance, group identification, and attitudes toward newcomer acceptance," Personality, vol. 10, no. 1, pp. 27-34, Oct. 2001.

[9] R. Shuter, "Introduction: New media across cultures - Prospect and promise," Journal of International \& Intercultural Communication, vol. 4, no. 4, pp. 241-245, November 2011.

[10] Z. Wang, J. B. Walther, and J. T. Hancock, "Social identification and interpersonal communication in computer-mediated communication: What you do versus who you are in virtual groups," Human Communication Research, vol. 35, pp. 59-85, January 2009.

[11] T. Tanaka, T. Kohyama, J. Takai, and T, Fujihara, "Factor analysis of Japanese students' perception of social network members: Compared to international students," Journal of Education for International Students of Hiroshima University, vol. 1, pp. 23-33. March 1997.

[12] T. Tanaka, Social Network and Social Skills of International Students, Nakanishiya: Kyoto, 2000, pp. 33-60

[13] K. V. Cleemput, "'I'll see you on IM, text, or call you': A social network approach of adolescents' use of communication media," Bulletin of Science, Technology \& Society, vol. 30, no. 2, pp. 75-85, April, 2010.

[14] H. Kim, G. J. Kim, H. W. Park, and R. E. Rice, "Configurations of relationships in different media: FTF, email, instant messenger, mobile phone, and SMS," Journal of Computer-Mediated Communication, vol. 12, no. 4, pp. 1183-1207, July 2007.

[15] S. Y. Ye, A. Toshimori, and T. Horita. (Sept. 2016). Relationship between college students' smartphone dependency, social networks and loneliness, considering the personality traits' effects. The Society of Socio-Informatics (SSI) 2016 National Annual Meeting, III-1. [Online]. Available: http://www.sgu.ac.jp/soc/ssi/papers/7.pdf

[16] S. Y. Ye and M. Murota, "Japanese students and Chinese students' mutual likeableness and their social networks," The 30th Annual Conference of Japan Society for Education and Technology, pp. 125-126, Sept. 2014

[17] T. Kobayashi and K. Ikeda, "The effect of mobile phone e-mailing in socialization in adolescents: Focusing on the homogeneity and heterogeneity of personal networks and tolerance," Japanese Journal of Social Psychology, vol. 23, no. 1, pp. 82-94, Aug. 2007.

[18] T. Kobayashi and K. Ikeda, "The effect of PC e-mail usage on social tolerance: Focusing on the mediating effect of communication with heterogeneous others," Japanese Journal of Social Psychology, vol. 24, no. 2, pp. 120-130, Nov. 2008.

[19] T. Kobayashi and K. Ikeda, "Does Internet usage increase the amount of social participation?: A comparison of the social use of the PC and mobile phone," JSIC Annual Report, pp. 39-49. March 2004.

[20] Y. Ogawara, "The effects of pronunciation learning strategies in Japanese learning," Journal of Linguistic Science of Tohoku University, vol. 2, pp. 1-12, Nov. 1998.

[21] B. M. Mulvaney. (1994). Gender differences in communication: An intercultural experience. [Online]. Available: http://feminism.eserver.org/gender/cyberspace/gender-differences.txt

[22] M. Matsuda, "Keitai in the 2000s," in Keitai in the 2000s: Maturation of Japanese Mobile Society, M. Matsuda, S. Dobashi and I. Tsuji, Ed. University of Tokyo Press, 2014, pp. 1-22.

[23] S. M. Kim, "The relationship between social network and cellularphone use for international students in Japan," The Bulletin of the Institute of Socio-Information and Communication Studies, the University of Tokyo, vol. 65, pp. 363-394, March 2003.

[24] S.Y. Ye and M. Murota, "The structure of international students' intimate social networks via different communication media," in Proc. The Society of Socio-Informatics (SSI) 2015 National Annual Meeting, Sep. 2015, pp. 44-49.

[25] G. M. Chen, "The impact of new media on intercultural communication in global context," China Media Research, vol. 8, no. 2, pp. 1-10, April 2012.

[26] R. M. Richardson and S. W. Smith, "The influence of high/low-context culture and power distance on choice of communication media: Students' media choice to communicate with professors in Japan and America," International Journal of Intercultural Relations, vol. 31, pp. 479-501, July 2007.

[27] E. Wurtz, "Intercultural communication on web sites: A cross-cultural analysis of web sites from high-context cultures and low-context cultures," Journal of Computer-Mediated Communication, vol. 11, pp. 274-299, October 2006.

[28] R. Shuter, "Intercultural new media studies: The next frontier in intercultural communication," Journal of Intercultural Communication Research, vol. 41, no. 3, pp. 219-237, November 2012. 
[29] S. Nagano and K. Fuji. (2016). Communication with weak ties and its effect on career reflection. Journal of Psychology. [Online]. 87(5). Available:

https://www.jstage.jst.go.jp/article/jjpsy/advpub/0/advpub_87.15039/ _pdf

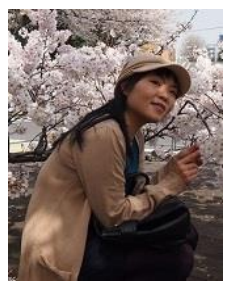

Shaoyu Ye was born in Canton, China, and is efficien in Chinese (both Cantonese and Mandarin), Japanese and English. She received her Ph.D (in Philosophy) from Tokyo Institute of Technology (2015); master of social psychology from Ochanomizu University (Japan) (2010); master of Japanese language and literature from Shanghai Institute of Studies University (2006), and a bachelor of Japanese language and literature from South China Normal University (2003)

Dr. Ye is a pioneer researcher specializing in media usage's effects on interpersonal communication especially intercultural communication and social support networks. She was also a research fellow of the Japan Society for the Promotion of Science (JSPS) from 2014-15 (DC2 \& PD).

Dr. Ye has been serving as assistant professor at the Faculty of Library, Information and Media Science, University of Tsukuba in Japan.

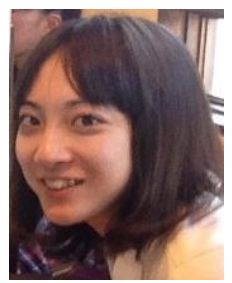

Erika Uchida is a senior student at College of Knowledge and Library Sciences, School of Informatics, University of Tsukuba in Japan. She is an advisee of Dr. Ye. 